\title{
ЛАТИНСКАЯ АМЕРИКА КАК ПРИОРИТЕТ ВНЕШНЕЙ ПОЛИТИКИ РЕСПУБЛИКИ БЕЛАРУСЬ (1992-2021 ГГ.)
}

\author{
A. В. ТИХОМИРОВ \\ Белорусский государственный университет \\ Минск, Республика Беларусь
}

\begin{abstract}
Аннотация. В статье оценивается место и роль стран Латинской Америки во внешней политике Республики Беларусь в 1992-2021 гг. Исследование отражает трансформацию взаимодействия Беларуси со странами Латинской Америки. Отмечено, что на раннем этапе существования независимого белорусского государства развитие отношений со странами Латинской Америки не входило в число приоритетных направлений его внешней политики. Во второй половине 1990-х гг., в условиях реализации установки на многовекторность во внешней политике деятельность белорусской дипломатии на латиноамериканском направлении стала более активной и целенаправленной. В 2000-х - первой половине 2010-х гг. сотрудничество с латиноамериканскими государствами вошло в число важных внешнеполитических приоритетов Беларуси. В развитии отношений с Латинской Америкой превалировал экономический компонент, хотя совпадение политических взглядов белорусского руководства и руководителей отдельных латиноамериканских государств повышало результативность межгосударственного общения. Во второй половине 2010-х гг. результативность деятельности белорусской дипломатии на латиноамериканском направлении снизилась по ряду причин. Однако белорусское руководство не пошло по пути кардинального пересмотра основ латиноамериканской политики, рассчитывая на то, что ранее созданные наработки позволят расширить сотрудничество в перспективе.
\end{abstract}

Ключевые слова: Республика Беларусь; Латинская Америка; внешняя политика; внешнеполитический приоритет; дипломатия; внешняя торговля.

Образец цитирования: Тихомиров A. B. Латинская Америка как приоритет внешней политики Республики Беларусь (1992-2021 гг.) // Актуальные проблемы международных отношений и глобального развития: сб. науч. ст. Минск, 2021. Вып. 9. С. 117-141. https://doi.org/10.33581/2311-9470-2021-9-117-141

Введение. Латинская Америка является регионом со сложной исторической и политической судьбой. Государства рассматриваемого региона (Бразилия, Аргентина, Мексика, Боливия, Эквадор, Колумбия, Чили, Уругвай, Парагвай и др.) располагают значительными природными богатствами и активно поставляют свою продукцию на мировые рынки. Долгое время они не принимали активного участия в мировой политике и не оказывали значительного воздействия на ход 
мировой истории. Однако в условиях глобализации во второй XX в. их значимость в мировой политике начала возрастать. Данное обстоятельство необходимо учитывать при формировании внешнеполитической стратегии Беларуси.

Новизна исследования заключается в рассмотрении латиноамериканского вектора в контексте внешнеполитической стратегии независимого белорусского государства. Целью данной статьи является выявление особенностей политики Беларуси в отношении стран Латинской Америки в 1990-х - 2010-х гг. и оценка результативности этой деятельности. Задачи исследования: выявить интересы Беларуси в Латинской Америке, раскрыть особенности политики белорусского государства в отношении стран указанного региона в 1990-х - 2010-х гг., оценить степень значимости стран Латинской Америки как партнеров Беларуси в рассматриваемый период.

Хронологические рамки исследования охватывают период с момента установления дипломатических отношений между Республикой Беларусь и рядом стран Латинской Америки в 1992 г. до 2021 г., когда руководство Беларуси приступило к переоценке некоторых аспектов внешней политики.

Актуальность исследования заключается в выявлении значения стран Латинской Америки для внешней политики Республики Беларусь и раскрытии особенностей политики белорусского государства на латиноамериканском направлении. Научный анализ позволяет углубить знания о реализации многовекторной внешней политики Республики Беларусь в конце XX - начале XXI вв., включая новейшие тенденции в развитии международных отношений.

Методология исследования. При проведении исследования автор опирался на принцип историзма. Им были использованы общенаучные (анализ, синтез, сравнение, обобщение, дедукция) и специальные исторические методы (историко-генетический, историкосравнительный структурный подход, системный подход). Применялись аналитические методики (метод описательного анализа), метод ивент-анализа (результаты сотрудничества Беларуси со странами Латинской Америки описываются в неореалистической парадигме, поскольку раскрывают роль государственных структур Беларуси в контексте осуществления ее внешней политики).

Объектом исследования является внешняя политика Республики Беларусь. Предмет исследования - политика белорусского государства в отношении стран Латинской Америки в 1992-2021 гг. 
Обзор источников и литературы по теме. Недостаточная проработанность соответствующей проблемы в научном плане предопределила активное обращение автора к первоисточникам: официальным заявлениям и выступлениям Президента Республики Беларусь; документам, опубликованным в сборниках по истории внешней политики Беларуси и журнале «Вестник Министерства иностранных дел» (журнал издавался в 1997-2007 гг.); статистическим сборникам по внешней торговле Беларуси.

В белорусской историографии первые публикации, освещавшие вопросы сотрудничества Республики Беларусь со странами Латинской Америки, появились в конце 2000-х гг. Первопроходцем стал А.А. Челядинский, который оценил результаты такого сотрудничества, достигнутые к концу первого десятилетия XXI в. [1].

Повышенный интерес белорусские ученые проявляли к проблемам взаимодействия со странами Латинской Америки в торговоэкономической сфере. Соответствующая проблематика нашла отражение в статьях аспиранта БГУ К. П. Андриевского и студента Гродненского государственного университета К. Д. Ананько [2; 3; 4]. К. П. Андриевский проанализировал результаты торгово-экономического сотрудничества Беларуси с рядом латиноамериканских стран (Аргентиной, Бразилией, Венесуэлой, Кубой), достигнутые к концу 2000-х гг. Он обратил внимание на то, что сближение Беларуси с латиноамериканским регионом в ряде случаев было обусловлено сходством политических позиций белорусского руководства и лидеров отдельных латиноамериканских государств, а также стремлением Беларуси диверсифицировать поставки в страну нефтепродуктов [2, с. 50]. С точки зрения К. П. Андриевского, белорусская сторона смогла достичь определенных успехов в развитии торговых связей с латиноамериканскими странами, однако действовала при этом недостаточно энергично и целенаправленно [2, с. 56].

К. Д. Ананько оценил результаты торгово-экономического сотрудничества Беларуси с Бразилией и Кубой. Характеризуя отношения с Кубой, он указывал на нестабильность двустороннего торгового оборота при сохранении востребованности ряда белорусских товаров (прежде всего сложнотехнической продукции) на кубинском рынке [3, с. 91-92]. При характеристике сотрудничества с Бразилией автор обращал внимание на очевидную выгоду торговых операций для белорусской стороны, но при этом высказывал мнение, что достигнутые 
результаты не в полной мере раскрывают имеющийся потенциал сотрудничества $[4$, с. 78$]$.

В ряде работ белорусские ученые рассматривали различные аспекты сотрудничества Республики Беларусь с отдельными государствами Латинской Америки. Повышенное внимание уделялось Кубе и Венесуэле - странам, наиболее близким Беларуси. В этом плане следует обратить внимание на публикации К. П. Андриевского и С. А. Кизимы $[5 ; 6 ; 7]$.

К. П. Андриевский считал, что деятельность белорусской дипломатии в отношении Кубы была нацелена на сохранение белорусского присутствия в этой стране, сформировавшегося во времена существования СССР. По его мнению, Куба стала своеобразным трамплином, с которого Беларусь смогла продвигаться в страны Латинской Америки [5, с. 94]. Оценивая состояние белоруссковенесуэльских отношений в статье, опубликованной в 2009 г., К. П. Андриевский отметил, что сотрудничество с этой страной позволило Беларуси найти нового партнера и союзника, открыло ряд возможностей для реализации экономического, научного и военного потенциала $[6$, с. 54].

Результативность белорусско-венесуэльского сотрудничества признавал и С. А. Кизима. В статье, опубликованной в 2010 г., он даже допускал возможность белорусско-венесуэльской интеграции в условиях глобализации [7, с. 25].

Аналитик Белорусского института стратегических исследований в Вильнюсе С. Богдан с помощью метода количественного анализа оценил эффективность сотрудничества белорусского государства с партнерами в Латинской Америке в различных сферах, отразив результаты своей исследовательской работы в специальном докладе, опубликованном в 2013 г. [8]. По мнению исследователя, пространство для маневра белорусской дипломатии ограничивали отсутствие опыта работы на данном направлении и географическая удаленность соответствующих государств. Реальными партнерами Беларуси в Латинской Америке по состоянию на 2012 г., с точки зрения С. Богдана являлись только Куба и Венесуэла.

За пределами Республики Беларусь проблематика ее взаимодействия со странами Латинской Америки большого интереса не вызывала (это касалось и исследователей Латинской Америки). Наиболее значимой научной работой стала совместная монография, подготовленная магистрантом БГУ из Эквадора Г. Гусманом (учебу в маги- 
стратуре он совмещал с исполнением обязанностей Первого секретаря посольства Эквадора в Минске) и А. Челядинским, опубликованная в 2017 г. [9]. Рассмотрев комплекс белорусско-эквадорских отношений в 2007-2016 гг., авторы пришли к выводу, что сближение двух государств было обусловлено политическими установками Президента Эквадора Р. Корреа [9]. Стремление эквадорского президента найти новых партнеров на международной арене поспособствовало быстрому выводу белорусско-эквадорских отношений на уровень стратегического партнерства.

Несколько аналитических работ, связанных с проблематикой белорусско-латиноамериканских отношений, подготовили исследователи из Украины и Польши: И. Плевако, Р. Чахор, Л. Стаськевич (особую ценность имела фундаментальная монография Л. Стаськевича, сориентированная именно на отношения Беларуси с латиноамериканскими странами) $[10 ; 11 ; 12]$. Указанные авторы рассматривали активность Беларуси в Латинской Америке в контексте многовекторности во внешней политике и объясняли ее стремлением белорусского руководства найти альтернативу России и странам коллективного Запада и получить дополнительную экономическую выгоду от развития сотрудничества со странами «Дальней дуги». По мнению украинских и польских исследователей, достигнутые результаты были неоднозначными, прочных связей с Латинской Америкой Беларуси также установить не удалось.

Результаты исследования. В первой половине 1990-х гг. развитие отношений со странами Латинской Америки не входило в число важных внешнеполитических приоритетов Республики Беларусь. В 1992 г. Беларусь установила дипломатические отношения с Аргентиной, Бразилией, Колумбией, Кубой, Мексикой, Уругваем, Чили. В том же году в Минске было открыто торгпредство Кубы. Однако для реализации активной политики на данном направлении не хватало квалифицированных кадров и финансовых средств. Серьезной проблемой являлся очевидный недостаток информации об особенностях развития и возможностях Беларуси (большинство латиноамериканских стран не имело представления даже о географическом расположении независимого белорусского государства).

До середины 1990-х гг. основным партнером Беларуси в латиноамериканском регионе была Куба, тесные экономические и культурные связи с которой сформировались еще во времена существования СССР. В 1994-1995 гг. прошло несколько встреч на высшем уровне, в 
ходе которых кубинская сторона проявила интерес к поставкам белорусских калийных и азотных удобрений и продуктов питания и предложила открыть в Гаване торгпредство Беларуси ${ }^{1}$. Стали расширяться белорусско-кубинские дипломатические контакты.

Однако в полной мере воспроизвести модель взаимодействия с Кубой образца СССР Республика Беларусь не могла ввиду радикально изменившихся внутренних и внешних обстоятельств. В первой половине 1990-х гг. белорусско-кубинское экономическое взаимодействие ограничивалось торговыми операциями. В белорусском экспорте на Кубу преобладали калийные удобрения, а в импорте с Кубы - сахар-сырец. Особенностью закупок кубинского сахара было то, что он приобретался не напрямую у кубинских производителей, а на международной бирже. Следствием этого было завышение цены на сахар и наличие отрицательного сальдо в торговле (положительное сальдо в торговле с Кубой Беларусь имела лишь в 1992 г.) [5, с. 54-55].

В середине 1990-х гг. диапазон общения Беларуси с Латинской Америкой стал расширяться. В октябре 1994 г. Минск посетил начальник департамента Европы Министерства внешних сношений Бразилии Ф. Жункейра, в декабре 1995 г. - делегация МИД Чили. Оба визита носили ознакомительный характер и достижением каких-либо конкретных договоренностей не увенчались ${ }^{2}$.

Более активными стали отношения Беларуси со странами Латинской Америки во второй половине 1990-х гг. В марте 1999 г. Первый заместитель Министра иностранных дел Республики Беларусь С. Мартынов объяснил этот факт заинтересованностью белорусского государства в расширении торгово-экономических контактов с соответствующими странами в рамках политики многовекторности ${ }^{3}$.

В конце 1990-х гг. представители правительства и МИД Беларуси осуществили ряд визитов в страны Латинской Америки (Колумбию, Бразилию, Уругвай, Чили и Перу). Эти визиты поспособствовали осознанию необходимости активизации работы по информированию потенциальных партнеров в латиноамериканском регионе о возможностях белорусских предприятий, расширения участия белорусских субъектов хозяйствования в крупнейших региональных ярмар-

\footnotetext{
${ }^{1}$ Беларусь - Куба: контакты после СССР // Белорус. деловая газета, 1994, 20 июня, с. 12.

${ }^{2}$ Беларусь - Бразилия: первые встречи // Белорус. деловая газета, 1994, 17 окт., с. 2; Белорусско-чилийское сотрудничество по российскому образцу // Белорус. деловая газета, 1995, 11 дек., с. 21.

${ }^{3}$ Сухова, К. Мартынов, С. «Это серьезный рынок» // Белорус. деловая газета, 1999, 17 апр., с. 14.
} 
ках и тендерах, усиления белорусского дипломатического присутствия в Латинской Америке. Конкретными результатами визитов стали протоколы о сотрудничестве министерства иностранных дел Республики Беларусь с аналогичными ведомствами в Республике Колумбия и Восточной Республики Парагвай. В 1999 г. было проведено первое заседание Белорусско-бразильской Торгово-промышленной палаты, созданной в рамках Федерации палат внешней торговли Бразилии при содействии МИД Беларуси ${ }^{4}$.

В марте 1998 г. в Минске появилось отделение посольства Перу, но в 2003 г. оно было закрыто по инициативе перуанской стороны.

Приоритетным партнером Беларуси в Латинской Америке во второй половине 1990-х гг. оставалась Куба. В 1997 г. эту страну посетили с визитами руководители Министерства иностранных дел и Министерства культуры Республики Беларусь, а также белорусские парламентарии. В том же году в Минске побывала кубинская правительственная делегация и состоялось первое заседание Межправительственной Белорусско-Кубинской комиссии по торговоэкономическому сотрудничеству 5 .

В 1997 г. кубинское торгпредство в Минске было преобразовано в посольство (посольство Кубы стало первым латиноамериканским дипломатическим представительством высокого уровня в Беларуси). В октябре 1998 г. Республика Беларусь открыла посольство в Гаване, которое также стало первым белорусским дипломатическим представительством высокого уровня в Латинской Америке.

Большое значение имел официальный визит на Кубу Президента Республики Беларусь в сентябре 2000 г. 3 сентября 2000 г. в Гаване были подписаны Договор о дружественных отношениях и сотрудничестве между Республикой Беларусь и Республикой Куба и Соглашение о торгово-экономическом сотрудничестве, послужившее право-

\footnotetext{
${ }^{4}$ Рабочий визит делегации Республики Беларусь во главе с Первым заместителем Министра иностранных дел Республики Беларусь С. Н. Мартыновым в Республику Колумбия // Вестник Министерства иностранных дел, 1998, № 2, с. 20; Визит делегации Республики Беларусь во главе с Первым заместителем Министра иностранных дел С. Н. Мартыновым в Восточную Республику Уругвай, Республику Чили и Республику Перу // Вестник Министерства иностранных дел, 1999, № 2, с. 33-40; Визит делегации Республики Беларусь во главе с Министром предпринимательства и инвестиций А. Ю. Сазоновым в Федеративную Республику Бразилию // Вестник Министерства иностранных дел, 1999, № 2, с. 43.

${ }^{5}$ Встреча в Палате представителей Национального собрания Республики Беларусь делегации Республики Куба, возглавляемой заместителем Министра иностранных инвестиций и экономического сотрудничества Н. Б. и де Мендосой // Вестник Министерства иностранных дел, 1997, № 1, c. 23.
} 
вой основой для развития взаимовыгодной торговли и иных видов экономического взаимодействия на условиях наибольшего благоприятствования. Белорусская и кубинская стороны договорились об осуществлении обмена товарами на безвалютной основе. В качестве перспективных направлений двустороннего сотрудничества были отмечены фармацевтика и медицина. Белорусская сторона выражала готовность открыть на Кубе сборочное производство тракторов, автомобилей, бытовой техники ${ }^{6}$.

Во время визита А. Лукашенко высказал мнение, что белорусско-кубинские отношения выходят на новый уровень ${ }^{7}$. В ноябре 2000 г. он включил сотрудничество с Кубой в число приоритетных направлений белорусской внешней политики ${ }^{8}$.

В 1995-2000 гг. объем белорусско-кубинского товарооборота увеличился с 7,8 до 46,2 млн долл. США 9 . На Кубу экспортировалась продукция белорусского машиностроения, легкой и радиоэлектронной промышленности. Взамен Беларусь получила кубинский сахар и цитрусовые $^{10}$. В торговле с Кубой Беларусь сохраняла отрицательное сальдо, объем которого в 2000 г. достиг 35,2 млн долл. США ${ }^{11}$. Однако доля Кубы в общем объеме белорусской внешней торговли товарами в 2000 г. составляла всего лишь $0,3 \%{ }^{12}$.

В 2000-х гг. значимость латиноамериканского направления во внешнеполитической стратегии Беларуси повысилась. Летом 2004 г. Президент Республики Беларусь обратил внимание белорусских дипломатов на то, что Латинская Америка неоправданно оказалась на второстепенном плане белорусской внешней политики. «Если сегодня проигнорировать потенциал этого региона, где нас ждут, завтра реальные шансы закрепиться на его рынках будут упущены», - подчеркнул он $^{13}$. В качестве наиболее перспективного партнера в Латинской Америке Главой белорусского государства была отмечена Бразилия ${ }^{14}$. Руководствуясь данными установками, белорусские дипло-

\footnotetext{
${ }^{6}$ Официальный визит Президента Республики Беларусь А. Г. Лукашенко в Республику Куба

// Вестник Министерства иностранных дел, 2000, № 3, с. 21.

${ }^{7}$ Там же, с. 20.

8 Знешняя палітыка Беларусі, т. 8. Минск : БГУ, 2008, с. 506.

${ }^{9}$ Подсчитано по: Внешняя торговля Республики Беларусь. 1995-2000. Минск, 2001. С. 61, 87.

${ }^{10}$ Официальный визит Президента Республики Беларусь А. Г. Лукашенко в Республику Куба

// Вестник Министерства иностранных дел, 2000, № 3, с. 19.

${ }^{11}$ Подсчитано по: Внешняя торговля Республики Беларусь. 1995-2000, с. 61, 87.

12 Подсчитано по: Внешняя торговля Республики Беларусь. 1995-2000, с. 56, 61; 87.

13 Знешняя палітыка Беларусі. Т. 9. Мінск: БДУ, 2013, с. 437-438.

${ }^{14}$ Там же, с. 438.
} 
маты осуществляли работу по расширению дипломатического присутствия в регионе. В 2000 г. было открыто посольство Республики Беларусь в Аргентине, в 2001 г. - Генеральное консульство Республики Беларусь в Рио-де-Жанейро. К началу 2003 г. Республика Беларусь поддерживала дипломатические отношения с 27 из 33 государств Латинской Америки и Карибского бассейна ${ }^{15}$.

В период с 2004 г. по 2010 г. представители белорусского правительства посетили Бразилию, Аргентину, Кубу, Эквадор, Боливию, Мексику и Венесуэлу. Делегации латиноамериканских государств также посещали Беларусь, хотя делали это реже, чем белорусские руководители. В частности, в 2005 г. в Минске побывала бразильская парламентская делегация, в 2008 г. - заместитель Министра экономики Мексики и министры иностранных дел Кубы и Никарагуа.

В марте 2010 г. Президент Республики Беларусь А. Лукашенко осуществил первый официальный визит в Бразилию. В том же году в Минске было открыто посольство Бразилии. В 2011 г. приступило к работе посольство Беларуси в г. Бразилиа (возникновение посольства послужило основанием для закрытия белорусского Генконсульства в Рио-де-Жанейро в 2013 г.).

Совпадение подходов Беларуси и стран Латинской Америки по ключевым международным проблемам создавало благоприятные условия для их успешной работы в ООН и Движении неприсоединения. Именно с проведением в Гаване XIV саммита Движения неприсоединения был связан очередной визит на Кубу Президента Республики Беларусь в сентябре 2006 г.

В сентябре 2005 г. в ходе работы 60-й сессии Генеральной Ассамблеи ООН в Нью-Йорке состоялась встреча министров иностранных дел Беларуси и Перу. В 2009 г. Беларусь впервые провела межмидовские консультации с Аргентиной.

Таким образом, в 2000-х гг. Республика Беларусь расширила дипломатическое присутствие и повысила уровень узнаваемости в Латинской Америке, стала лучше разбираться в местных проблемах и особенностях работы на рынках государств данного региона. Согласно белорусским статистическим данным, в 2000-2005 гг. объем товарооборота Беларуси с южноамериканскими странами увеличился с 240,8 до 372,6 млн. долл. США ${ }^{16}$. В 2010 г. соответствующий показа-

\footnotetext{
${ }^{15}$ Там же, с. 288.

${ }^{16}$ Внешняя торговля Республики Беларусь. Статистический сборник. Минск, 2006, с. 53.
} 
тель достиг 2,7 млрд., в 2011 г. повысился до 3,3 млрд. долл. США ${ }^{17}$. Однако в торговле с соответствующими государствами отсутствовала системность. После азиатского финансового кризиса 1997 г. страны Латинской Америки не имели возможности закупать белорусскую продукцию в больших объемах, несмотря на ее относительную дешевизну. Новые проблемы породил мировой финансовый и экономический кризис, разразившийся в 2008 г. Негативно отражались на результатах торговли недостаточная гибкость при определении цен на белорусскую продукцию, а также недооценка белорусской стороной значимости маркетингового сопровождения и сервисного обслуживания поставляемой техники [2, с. 52; 55].

В начале 2000-х гг. белорусская сторона попыталась выступить в роли проводника латиноамериканских продуктов на российский рынок. В частности, именно так обстояло дело с закупкой кубинского сахара-сырца, его последующей переработкой на белорусских предприятиях и реализацией в России (все торговые операции осуществляло совместное белорусско-кубинско-канадское предприятие «Белатинсахар») [2, с. 55]. Введение российским правительством ограничений на поставки сахара из Беларуси в 2005 г. привело к сокращению закупок белорусской стороной кубинского сахара (см. табл. 1).

Более значимыми для Беларуси в 2000-х гг. являлись торговые отношения с Бразилией и Аргентиной. Товарооборот с Бразилией к концу указанного десятилетия превысил 1 млрд долл. США, а в 2011 г. достиг 1,6 млрд долл. США ${ }^{18}$. При этом в торговле с Бразилией Беларусь сохраняла положительное сальдо (в структуре экспортных поставок в Бразилию преобладали калийные удобрения, в структуре импорта из Бразилии - сахар-сырец). Товарооборот Беларуси с Аргентиной в 2000-2010 гг. увеличился с 15,5 до 193,4 млн долл. США, в 2011 г. составил 227,3 млн долл. США ${ }^{19}$. В торговле с Аргентиной Беларусь сохраняла отрицательное сальдо (см. табл. 1).

Особый характер приобрели отношения Республики Беларусь с Боливарианской Республикой Венесуэла. Начало развитию политического диалога с этой страной положила совместная работа в рамках Движения неприсоединения [6, с. 51]. В октябре 2005 г. состоялся первый визит в Минск венесуэльского министра иностранных дел А. Араке. В июле 2006 г. впервые в истории Беларусь посетил Прези-

\footnotetext{
${ }^{17}$ Внешняя торговля Республики Беларусь. Статистический сборник. Минск, 2012, с. 74.

${ }^{18}$ Внешняя торговля Республики Беларусь. Статистический сборник. Минск, 2012, с.40; 45.

${ }^{19}$ Там же.
} 
дент Боливарианской Республики Венесуэла У. Чавес. Визит проходил в дружественной атмосфере, а его результатом стала договоренность о выводе белорусско-венесуэльских отношений на уровень стратегического партнерства [6, с. 52]. В декабре 2006 г. было открыто посольство Беларуси в Венесуэле, в октябре 2007 г. к работе в Минске приступило посольство Венесуэлы. Во второй половине 2000-х гг. интенсивность белорусско-венесуэльского политического диалога на высшем уровне обрела предельно высокий уровень интенсивности. В 2007-2010 гг. визиты У. Чавеса в Беларусь осуществлялись ежегодно. В сентябре 2006 г. У. Чавес и А. Лукашенко провели встречу на полях XIV саммита Движения неприсоединения в Гаване. В 2007 и 2010 гг. президент Республики Беларусь осуществил два визита в Венесуэлу. В 2009 г. приступила к работе БелорусскоВенесуэльская комиссия высокого уровня.

В июле 2009 г. на совещании с участием руководителей белорусских загранучреждений А. Лукашенко выделил развитие отношений с Венесуэлой в качестве одного из важнейших приоритетов внешней политики белорусского государства ${ }^{20}$. В апреле 2011 г. он приравнял результативность сотрудничества с Венесуэлой к результативности сотрудничества с Китаем ${ }^{21}$.

Активный политический диалог способствовал быстрому расширению договорно-правовой базы двустороннего сотрудничества и росту белорусско-венесуэльской торговли, прежде всего за счет увеличения белорусского экспорта в Венесуэлу. Во второй половине 2000-х гг. к калийным удобрениям, ранее преобладавших в белорусском экспорте в рассматриваемую страну, добавились тракторы, самосвалы «МАЗ» и «БелАЗ», дорожная техника, сухое молоко [6, c. 52]. Соответственно, объем белорусского экспорта вырос с 15,6 млн. долл. США в 2005 г. до 42,7 млн. долл. США в 2007 г. ${ }^{22}$

В 2007 г. была достигнута договоренность о содействии белорусской стороны в строительстве в Венесуэле кирпичного завода.

\footnotetext{
20 Лукашенко А. Г. Беларусь не отступит от принципа проведения многовекторной политики // Президент республики Беларусь [Электронный ресурс]. 23.07.2009. URL: https://president. gov.by/ru/events/belarus-ne-otstupit-ot-printsipa-provedenija-mnogovektornoj-politiki-4906 (дата обращения: 15.08.2021).

21 Лукашенко А. Г. Послание белорусскому народу и Национальному собранию // Президент Республики Беларусь [Электронный ресурс]. 21.04.2011. URL: https://president.gov.by/ru/ events/poslanie-belorusskomu-narodu-i-natsionalnomu-sobraniju-5804 (дата обращения: 15.08.2021).

${ }^{22}$ Внешняя торговли Республики Беларусь. Статистический сборник. Минск, 2006, с. 55; Внешняя торговля Республики Беларусь. Статистический сборник. Минск, 2010, с. 34.
} 
Также белорусы должны были осуществить газификацию г. Баринаса, реконструировать центральный район Каракаса и построить район на 5 тыс. квартир в г. Техернос [6, с. 53]. В 2012 г. в Венесуэле был налажен выпуск белорусских тракторов.

В 2007 г. руководство Венесуэлы допустило белорусов к разработке нефти и природного газа в штате Ансоатеги на блоке Хунин и месторождении Лаго-Медиа. Разработками нефти занималось СП «Петролера БелоВенесолана (ПетроВенБел)», приступившее к работе 8 декабря 2007 г. Изначально предполагалось, что белорусская сторона реализует добытую нефть в западном полушарии, а полученную выручку использует для закупки нефти в России [6, с. 53]. Однако в условиях осложнения белорусско-российских отношений в 2010 г. было решено направить венесуэльскую нефть непосредственно на белорусские предприятия. Первая венесуэльская нефть поступила в Беларусь в мае 2010 г. $^{23}$

Реализация нефтяных проектов с Венесуэлой привела к диверсификации поставок энергоносителей в Беларусь и способствовала существенному увеличению белорусско-венесуэльского товарооборота. Так, в 2008 г. он достиг 183,4 млн. долл. США, в 2009 г. - 230,6 млн., в 2010 г. - 1,5 млрд. ${ }^{24}$ В 2010 г. в торговле Беларуси с Венесуэлой образовалось внушительное отрицательное сальдо в объеме около 850 млн. долл. США ${ }^{25}$.

В конце 2010 г. белорусская сторона заменила прямые поставки нефти из Венесуэлы своп-схемой с участием Азербайджана ${ }^{26}$. В июне 2012 г. белорусское правительство признало нерентабельность прямых поставок нефти из Венесуэлы ${ }^{27}$.

Успехи в развитии сотрудничества с Венесуэлой подталкивали белорусскую дипломатию к поиску новых партнеров в Латинской Америке. В июне 2009 г. А. Лукашенко положительно оценил трех-

\footnotetext{
${ }^{23}$ Томашевская О. Россия может оштрафовать Белоруссию // Время новостей. [Электронный pecypc]. 21 мая 2010. URL: http://www.vremya.ru/2010/86/5/254203.html (дата обращения: 20.07.2021).

${ }^{24}$ Внешняя торговля Республики Беларусь. Статистический сборник. Минск, 2010. С.34; Статистический ежегодник Республики Беларусь, 2012. Минск, 2013. с. 674.

${ }^{25}$ Статистический ежегодник Республики Беларусь, 2012. Минск, 2013, с. 674.

26 Жахов Ф. Нефтяники накинули по \$45 // Белгазета, 2011, 10 янв., с. 4.

${ }^{27}$ Беларусь может отказаться от венесуэльской нефти // Белорусское телеграфное агентство (БелТА) [Электронный ресурс]. 07.06.2012 URL: http://www.belta.by/ru/all_news/economics/ Belarus-mozhet-otkazatsja-ot-importa-venesuelskoj-nefti---Semashko_i_599672.html (дата обращения: 25.08.2012); Семашко: с июня мы уже не получаем нефть из Венесуэлы // Бел. новости [Электронный ресурс]. 22.06.2012 URL: http://naviny.by/rubrics/economic/2012/ 06/22/ic_news_113_395822/ (дата обращения: 22.06.2012).
} 
кратный рост экспорта белорусской продукции в латиноамериканские страны и призвал обеспечить устойчивость присутствия на местных рынках посредством формирования кооперационных связей и создания сборочных производств ${ }^{28}$. В первой половине 2010 -х гг. деятельность на латиноамериканском направлении рассматривалась белорусским руководством как успешная и перспективная. Установка на необходимость продолжения работы на данном направлении присутствовала в программных выступлениях Главы белорусского государства в 2011, 2012, 2013, 2014 и 2015 гг. ${ }^{29}$ В 2014 г. Президент Республики Беларусь выделил в качестве перспективных партнеров Боливию, Венесуэлу, Кубу и Эквадор, в 2015 г. добавил к указанным государствам Никарагуа.

В 2012 г. Президент Республики Беларусь осуществил визиты в Эквадор и на Кубу. В 2013 г. нашу страну посетили Президент Венесуэлы Н. Мадуро, Президент Боливии Э. Моралес и Президент Эквадора Р. Корреа. В том же году состоялся визит в Беларусь вицепрезидента Эквадора Х. Гласа.

В мае 2015 г. на полях саммита БРИКС в Уфе А. Лукашенко встретился с Президентом Бразилии Д. Руссефф, обсудив с ней актуальные проблемы двусторонних отношений. В сентябре того же года в рамках 70-й сессии Генеральной Ассамблеи ООН в Нью-Йорке состоялась встреча президентов Беларуси и Эквадора.

\footnotetext{
28 Лукашенко А. Г. Послание белорусскому народу и Национальному собранию Республики Беларусь// Президент Республики Беларусь [Электронный ресурс]. 23.06.2009. URL: https://president.gov.by/ru/events/poslanie-belorusskomu-narodu-i-natsionalnomu-sobraniju-respub liki-belarus-5882 (дата обращения: 15.08.2021).

29 Лукашенко А. Г. Послание белорусскому народу и Национальному собранию // Президент Республики Беларусь [Электронный ресурс]. 21.04.2011. URL: https://president.gov.by/ru/ events/poslanie-belorusskomu-narodu-i-natsionalnomu-sobraniju-5804. (дата обращения: 18.08.2021); Лукашенко А. Г. Послание Президента белорусскому народу и Национальному собранию // Президент Республики Беларусь [Электронный ресурс]. 08.05.2012. URL: https://president.gov.by/ru/events/poslanie-prezidenta-belorusskomu-narodu-i-natsionalnomusobraniju-5798 (дата обращения: 18.08.2021); Лукашенко А. Г. Послание белорусскому народу и Национальному собранию // Президент Республики Беларусь [Электронный ресурс]. 19.04.2013. URL: https://president.gov.by/ru/events/poslanie-k-belorusskomu-narodu-i-natsional nomu-sobraniju-8567. (дата обращения: 18.08.2021); Лукашенко А. Г. Послание Президента белорусскому народу и Национальному собранию // Президент Республики Беларусь [Электронный ресурс]. 22.04.2014. URL: https://president.gov.by/ru/events/aleksandr-lukashenko -obraschaetsja-s-ezhegodnym-poslaniem-k-belorusskomu-narodu-i-natsionalnomu-sobraniju-8549 (дата обращения: 18.08.2021); Лукашенко А. Г. Обращение с посланием к белорусскому народу и Национальному собранию // Президент Республики Беларусь [Электронный ресурс]. 29.04.2015. URL: https://president.gov.by/ru/events/obraschenie-s-poslaniem-k-belorus skomu-narodu-i-natsionalnomu-sobraniju-11301 (дата обращения: 18.08.2021).
} 
Диалог осуществлялся также по линии парламентов и правительств. Наиболее результативным было межпарламентское сотрудничество Беларуси с Бразилией и Эквадором. Весьма активно взаимодействовали в этот период и внешнеполитические ведомства.

В 2012 г. белорусские предприятия вошли на эквадорский нефтяной рынок. Разработку нефтяных месторождений Эквадора осуществляло СП «Сервис Ойл Эквадор Эквасервойл», контрольным пакетом акций которого владела «Белоруснефть» ${ }^{30}$.

В 2013 г. были проведены первые заседания Совместной Белорусско-Боливийской комиссии по торгово-экономическому сотрудничеству и Белорусско-Эквадорской комиссии по торговле и экономическому сотрудничеству. В 2015 г. первое заседание провела Белорусско-Аргентинская комиссия по торгово-экономическому сотрудничеству. В том же году состоялось второе заседание БелорусскоЭквадорской комиссии по торговле и экономическому сотрудничеству. В 2014 г. приступили к работе посольство Эквадора в Беларуси и посольство Беларуси в Эквадоре.

Во второй половине 2010-х гг. отношения Беларуси со странами Латинской Америки стали более сдержанными. В первую очередь это было обусловлено кризисными явлениями в политике и экономике латиноамериканских государств, которые сопровождались либо их дестабилизацией, либо приходом к власти правых режимов, в меньшей степени склонных к сотрудничеству с Беларусью. Так, к примеру, обстояло дело с Бразилией, руководство которой после прихода к власти в 2019 г. Ж. Болсонару свернуло политический диалог с официальным Минском. Взаимодействие Беларуси с Венесуэлой стало проблематичным не только из-за глубокого политического и экономического кризиса в этой стране, возникшего после смерти У. Чавеса в 2013 г., но и из-за санкций, введенных США и ЕС в отношении Венесуэлы в 2019 г.

Определенную роль сыграло и то, что руководство Беларуси во второй половине 2010-х гг. попыталось нормализовать отношения с ЕС и США. Соответственно, значимость географически отдаленных стран Латинской Америки во внешнеполитической стратегии Беларуси снизилась. В 2016-2020 гг. Глава белорусского государства не осуществил ни одного визита в латиноамериканские страны.

\footnotetext{
${ }^{30}$ Бутович Н. В Эквадоре собираются отсудить у «Белоруснефти» \$60 млн за долги // Комсомольская правда в Беларуси [Электронный ресурс]. 21.04.2021. URL: https://www.kp.by online/news/4266552/ (дата обращения: 20.08.2021).
} 
Объем товарооборота Беларуси со странами Латинской Америки сократился, причем в наибольшей мере спад проявился в торговле с Венесуэлой и Кубой (см. табл. 2 и 3). С 2014 г. венесуэльская сторона перестала рассчитываться за поставляемую белорусскую продукцию. По состоянию на 2018 г. ее задолженность перед МТЗ и МАЗ составляла около 110 млн. долл. В 2018 г. прекратился выпуск белорусской техники на территории Венесуэлы ${ }^{31}$.

Конфликтная ситуация возникла в отношениях с Эквадором. В 2020 г. эквадорская компания Servicios Drilling Technologies (SDT) обвинила «Белоруснефть» в присвоении средств, предназначенных для бурения скважин и содержания необходимой инфраструктуры, и потребовала выплаты свыше 60 млн долл. В марте 2021 г. STD направила в Министерство энергетики и невозобновляемых природных ресурсов Эквадора жалобу, где указывалось, что белорусская сторона «не привлекла в Эквадор финансирование, как это было предусмотрено в двустороннем соглашении с правительством», и продолжает «ежемесячно взимать вознаграждение, не рассчитываясь по долгам, как перед компаниями, так и перед госучреждениями» ${ }^{32}$. Также иск против «Белоруснефти» был направлен в суд.

Впрочем, возникшие трудности не привели к радикальному пересмотру основ белорусской политики на латиноамериканском направлении. В 2019 г. Республика Беларусь установила дипломатические отношения со всеми 33 государствами Латинской Америки и Карибского бассейна (последними государствами, с которыми были установлены такие отношения, стали Содружество Багамских островов и Барбадос). В том же году было принято решение об открытии посольства Республики Беларусь в Колумбии. Почетные консулы Беларуси действовали в Боливии, Бразилии, Доминиканской Республике, Колумбии, Мексике, Никарагуа, Эквадоре, Уругвае ${ }^{33}$.

Установка на сохранение отношений стратегического партнерства была подтверждена во время визитов в Минск Президента Венесуэлы Н. Мадуро в октябре 2017 г. и президента Кубы М. Диас-

\footnotetext{
31 Эйсмонт М. Как работают белорусские компании в Венесуэле? // Нар. воля. 2018. 27 крас. C. 3 .

32 Бутович Н. В Эквадоре собираются отсудить у «Белоруснефти» $\$ 60$ млн за долги // Комсомольская правда в Беларуси [Электронный ресурс]. 21.04.2021. URL: https://www.kp.by online/news/4266552/ (дата обращения: 20.08.2021).

${ }^{33}$ Беларусь и страны Латинской Америки // Министерство иностранных дел Республики Беларусь [Электронный ресурс]. 2021. URL: https://mfa.gov.by/bilateral/america/latin_america/ (дата обращения: 20.08.2021).
} 
Канеля Бермудеса в октябре 2019 г. ${ }^{34}$ В мае 2019 г. МИД Беларуси решительно осудил попытку смещения Н. Мадуро, подчеркнув, что считает именно его законным президентом Венесуэлы 35 .

До 2017 г. высокая степень интенсивности политического диалога сохранялась в отношениях Беларуси с Эквадором. В 2016 г. парламенты Республики Беларусь и Эквадора подписали Соглашение о сотрудничестве. В сентябре того же года в Нью-Йорке была проведена встреча министров иностранных дел Беларуси и Эквадора. В 2017 г. Беларусь посетил Министр-координатор по вопросам безопасности Эквадора С. Навас. Однако после победы на президентских выборах в Эквадоре в мае 2017 г. Л. Морено белорусско-эквадорские отношения перешли в фазу охлаждения. Общение глав дипломатических ведомств двух стран прекратилось после визита в Минск в 2018 г. Министра иностранных дел Эквадора М. Ф. Эспиносы. В том же году власти Эквадора решили закрыть посольство в Минске, сославшись на бюджетные проблемы ${ }^{36}$. Ответной реакцией стало закрытие белорусского посольства в Эквадоре (деятельность посольства прекратилась в июле 2021 г.).

Активную работу по сохранению и укреплению связей с Латинской Америкой осуществляли белорусские дипломаты. В 2016 г. в Нью-Йорке состоялась встреча министров иностранных дел Беларуси и Аргентины, а в Минске побывал с визитом Первый заместитель Министра иностранных дел Аргентины. В 2017 г. первое заседание провела Белорусско-Бразильская комиссии по торгово-экономическому сотрудничеству. В 2017-2018 гг. заместитель Министра иностранных дел Республики Беларусь Е. Шестаков осуществил визиты в Никарагуа, Парагвай, Аргентину, Перу и Колумбию. В 2016 г.

\footnotetext{
34 Лукашенко А. Г. Переговоры с Президентом Венесуэлы Николасом Мадуро // Президент Республики Беларусь [Электронный ресурс]. 05.10.2017. URL: https://president.gov.by/ru/ events/peregovory-c-prezidentom-bolivarianskoj-respubliki-venesuela-nikolasom-maduro17221\#block-after-media-scroll (дата обращения: 23.08/2021); Лукашенко, А. Г. Переговоры с Президентом Кубы Мигелем Марио Диас-Канелем Бермудесом // Президент Республики Беларусь [Электронный ресурс]. 23.10.2019. URL: https://president.gov.by/ru/events/peregovory -s-prezidentom-kuby-migelem-mario-dias-kanelem-bermudesom-22246\#block-after-media-scroll (дата обращения: 23.08.2021).

35 Заявление МИД Беларуси в связи с событиями в Венесуэле // Министерство иностранных дел Республики Беларусь [Электронный ресурс]. 01.05.2019. URL: http://mfa.gov.by/press/ news_mfa/dfbf8d0583831d4a.html (дата обращения: 20.08.2021).

36 Эквадор намерен начать процедуру закрытия посольства в Минске в ближайшее время // Белорусское телеграфное агентство (БелТА). [Электронный ресурс]. 05.09.2018. URL: https://www.belta.by/politics/view/ekvador-nameren-nachat-protseduru-zakrytija-posolstva-vminske-v-blizhajshee-vremja-316691-2018/ (дата обращения: 20.08.2021).
} 
Беларусь провела межмидовские консультации с Чили и Уругваем, в 2017 г. - с Аргентиной, Бразилией и Парагваем, в 2018 г. - с Аргентиной, Колумбией, Перу, Панамой и Эквадором, в 2019 г. - с Чили.

В 2020 г. суммарный объем белорусского экспорта в Латинскую Америку превысил 701,1 млн. долл. США ${ }^{37}$. Основу экспорта составляли минеральные удобрения и сложнотехническая продукция. Наиболее значимыми внешнеторговыми партнерами Беларуси в регионе в конце 2010-х гг. были Бразилия и Эквадор (см. табл. 3).

Развитию туристических связей Беларуси со странами Латинской Америки способствовало наличие соглашений о безвизовых поездках граждан. В 2007 г. такое соглашение было подписано с Венесуэлой, в 2008 г. - с Эквадором, в 2013 г. - с Бразилией, в 2016 г. - с Аргентиной, в 2018 г. - с Сент-Китс и Невис. В 2018-2019 гг. Президент Республики Беларусь в одностороннем порядке облегчил порядок въезда на территорию Беларуси граждан Антигуа и Барбуды, Барбадоса, Гаити, Доминики, Мексики, Никарагуа, Панамы, Перу, Сент-Винсент и Гренадин, Уругвая, Чили, Эль-Сальвадора (при условии их прибытия через Национальный аэропорт «Минск») $)^{38}$.

В условиях эпидемии COVID-19 в 2020 г. контакты между Беларусью и странами Латинской Америки были сведены к минимуму, однако в 2021 г. отношения со странами Латинской Америки начали выходить из состояния временного застоя. В частности, в июле 2021 г. в Минске побывала парламентская делегация из Колумбии.

В феврале 2021 г. Президент Республики Беларусь в выступлении на VI Всебелорусском собрании вновь указал на необходимость работы со странами Латинской Америки в контексте отношений со странами «Дальней дуги» ${ }^{39}$. Таким образом, можно предположить, что в новом десятилетии XXI в. деятельность белорусской дипломатии в Латинской Америке будет сориентирована на сохранение связей с традиционными партнерами при одновременном продолжении поиска перспективных партнеров в рассматриваемом регионе.

\footnotetext{
${ }^{37}$ Беларусь и страны Латинской Америки // Министерство иностранных дел Республики Беларусь [Электронный ресурс]. 2021. URL: https://mfa.gov.by/bilateral/america/latin_america/ (дата обращения: 19.08.2021).

${ }^{38}$ Указ Президента Республики Беларусь №300 «Об установлении безвизового порядка въезда и выезда иностранных граждан» от 7 августа 2019 г. // Национальный правовой интернетпортал Республики Беларусь [Электронный ресурс]. URL: https://pravo.by/document /?guid=3871\&p0=P31900300 (дата обращения: 20.08.2021).

39 Лукашенко А. Г. Доклад Президента Беларуси на VI Всебелорусском народном собрании // Президент Республики Беларусь [Электронный ресурс]. 11.02.2021. URL: https://president. gov.by/ru/events/shestoe-vsebelorusskoe-narodnoe-sobranie (дата обращения: 23.08.2021).
} 
Заключение. В первой половине 1990-х гг. взаимодействие со странами Латинской Америки не входило в число приоритетных направлений внешней политики белорусского государства. Интерес к ним проявился лишь во второй половине 1990-х гг. в условиях официально провозглашенной руководством Республики Беларусь установки на многовекторность во внешней политике и поиск новых партнеров на международной арене. В первой половине 2000-х гг. развитие дружественных и взаимовыгодных отношений со странами Латинской Америки вошло в число стратегических приоритетов внешней политики Республики Беларусь.

В 2000-х - первой половине 2010-х гг. деятельность белорусской дипломатии на латиноамериканском направлении стала более системной и результативной. Налаживанию связей со странами Латинской Америки поспособствовало присутствие Беларуси в Движении неприсоединения. Достигнутые результаты рассматривались как элемент успешной деятельности белорусской дипломатии. Если в 1990-х гг. основным и, по сути, единственным партнером Беларуси в латиноамериканском регионе была Куба, то в новом десятилетии перечень стран, с которыми белорусская сторона поддерживала политический диалог и осуществляла торговые операции, существенно расширился. Большое значение для Беларуси имела торговля с Бразилией и Аргентиной. На уровень стратегического партнерства были выведены отношения с Венесуэлой и Эквадором.

Деятельность белорусского государства на латиноамериканском направлении была направлена на защиту экономических интересов, однако сходство политических установок руководства Беларуси и отдельных латиноамериканских государств облегчало двусторонние контакты и повышало результативность сотрудничества в различных сферах (так обстояло дело в случаях с Кубой, Венесуэлой, Бразилией и Эквадором).

Результаты сотрудничества выглядели противоречиво. Республика Беларусь смогла вывести свою продукцию (в т. ч. сложнотехническую) на латиноамериканский рынок и реализовать ряд совместных инвестиционных проектов в латиноамериканском регионе, но основу экспорта в Латинскую Америку составляли минеральные удобрения, а эффективность инвестиционного сотрудничества оставалась невысокой. Развитию сотрудничества препятствовали недостаток информации о Беларуси и ее возможностях, слабая гибкость и оперативность белорусских предприятий, недооценка значимости торговой 
логистики и сервисного обслуживания поставляемой белорусской техники. Негативное воздействие на состояние отношений Беларуси с латиноамериканскими странами оказывали политические и экономические кризисы в этих странах.

Во второй половине 2010-х гг. значимость латиноамериканских стран во внешней политике Республики Беларусь снизилась. Политический диалог с этими странами стал осуществляться преимущественно по дипломатическим каналам. Сократился объем торговли с Латинской Америкой (весьма наглядно спад проявился в торговых отношениях с Кубой и Венесуэлой). Однако белорусское руководство не пошло по пути кардинального пересмотра основ латиноамериканской политики, рассчитывая на то, что ранее достигнутые наработки позволят расширить сотрудничество со странами рассматриваемого региона в перспективе. 


\section{Таблица 1}

Торговля товарами Республики Беларусь со странами Латинской Америки в 2005-2010 гг. (экспортно-импортные операции)

млн. долл. США

\begin{tabular}{|c|c|c|c|c|c|c|c|c|c|c|c|c|}
\hline & \multicolumn{2}{|c|}{2005 г. } & \multicolumn{2}{|c|}{2006 г. } & \multicolumn{2}{|c|}{2007 г. } & \multicolumn{2}{|l|}{2008 Г. } & \multicolumn{2}{|c|}{2009 Г. } & \multicolumn{2}{|c|}{2010 г. } \\
\hline & эксп. & имп. & эксп. & имп. & эксп. & имп. & эксп. & имп. & эксп. & имП. & эксп. & имп. \\
\hline Аргентина & 3,4 & 23,2 & 3,6 & 71,3 & 6,0 & 67,9 & 26,0 & 115,4 & 3,5 & 102,1 & 23,0 & 193,4 \\
\hline Бразилия & 167,5 & 142,3 & 207,4 & 210,0 & 371,1 & 105,9 & 1073,7 & 155,1 & 444,8 & 118,4 & 705,5 & 157,3 \\
\hline Венесуэла & 15,6 & 0,0 & 6,0 & 0,0 & 42,7 & 0,0 & 173,1 & 0,1 & 230,6 & 0,0 & 302,4 & 1152,3 \\
\hline Колумбия & 0,8 & 2,5 & 1,9 & 5,7 & 23,3 & 6,1 & 79,9 & 5,9 & 49,1 & 6,4 & 45,7 & 17,7 \\
\hline Куба & 13,2 & 5,7 & 10,3 & 11,6 & 14,8 & 6,4 & 35,1 & 14,6 & 15,2 & 0,9 & 6,9 & 0,5 \\
\hline Мексика & 7,6 & 6,0 & 6,0 & 10,2 & 4,4 & 16,9 & 10,0 & 23,5 & 11,4 & 17,5 & 30,3 & 17,0 \\
\hline Перу & 3,2 & 1,3 & 0,0 & 0,0 & 0,0 & 0,0 & 0,0 & 0,0 & 0,0 & 0,0 & 0,1 & 3,6 \\
\hline Уругвай & 2,1 & 1,1 & 0,0 & 0,0 & 0,0 & 0,0 & 0,0 & 1,9 & 0,0 & 0,8 & 8,2 & 1,7 \\
\hline Чили & 3,3 & 4,6 & 0,0 & 6,4 & 0,0 & 12,3 & 0,0 & 13,0 & 0,0 & 12,6 & 1,8 & 11,6 \\
\hline Эквадор & - & 7,2 & 6,6 & 12,8 & 8,2 & 15,9 & 28,4 & 32,8 & 8,8 & 25,4 & 12,1 & 26,5 \\
\hline
\end{tabular}

Источник: Внешняя торговля Республики Беларусь. Статистический сборник. Минск, 2006. С. 56-63; Внешняя торговля Республики Беларусь. Статистический сборник. Минск, 2010. С. 34-43; Внешняя торговля Республики Беларусь. Статистический сборник. Минск, 2012. С. 40-49. 


\section{Таблица 2}

Торговля товарами Республики Беларусь со странами Латинской Америки в 2011-2015 гг. (экспортно-импортные операции)

млн. долл. США

\begin{tabular}{|c|c|c|c|c|c|c|c|c|c|c|}
\hline & \multicolumn{2}{|l|}{2011 г. } & \multicolumn{2}{|c|}{2012 г. } & \multicolumn{2}{|c|}{2013 г. } & \multicolumn{2}{|c|}{2014 г. } & \multicolumn{2}{|c|}{2015 г. } \\
\hline & эксп. & имп. & Эксп. & имП. & эксп. & имп. & ЭКсп. & имп. & эксп. & имП. \\
\hline Аргентина & 60,2 & 167,1 & 8,0 & 188,2 & 1,0 & 221,4 & 4,8 & 152,7 & 9,7 & 57,0 \\
\hline Бразилия & 1224,1 & 365,2 & 801,7 & 205,1 & 518,6 & 128,7 & 709,5 & 156,2 & 521,2 & 124,5 \\
\hline Венесуэла & 198,8 & 1129,8 & 254,4 & 326,4 & 83,0 & 0,3 & 99,7 & 0,0 & 27,0 & 0,0 \\
\hline Колумбия & 95,7 & 8,0 & 29,2 & 7,1 & 12,0 & 8,2 & 1,7 & 8,6 & 16,3 & 12,0 \\
\hline Куба & 34,1 & 44,8 & 30,6 & 13,1 & 36,3 & 24,4 & 18,8 & 26,0 & 21,8 & 31,0 \\
\hline Мексика & 23,5 & 15,6 & 18,6 & 20,9 & 13,9 & 29,7 & 3,1 & 53,7 & 4,2 & 37,9 \\
\hline Парагвай & - & 0,0 & 4,4 & 0,0 & 1,2 & 0,0 & 15,6 & 0,0 & 14,0 & 0,0 \\
\hline Перу & 0,0 & 3,0 & 0,0 & 3,6 & 1,1 & 5,2 & 0,1 & 5,1 & 0,4 & 21,7 \\
\hline Уругвай & 27,4 & 3,4 & 5,4 & 3,4 & 16,8 & 4,3 & 11,8 & 4,8 & 9,3 & 2,7 \\
\hline Чили & 17,8 & 11,6 & 4,8 & 6,9 & 2,0 & 10,7 & 0,8 & 38,6 & 0,8 & 13,2 \\
\hline Эквадор & 20,8 & 26,3 & 5,2 & 10,8 & 5,3 & 19,5 & 13,5 & 23,1 & 4,2 & 73,3 \\
\hline
\end{tabular}

Источник: Экспорт товаров из Республики Беларусь по отдельным странам вне СНГ // Национальный статистический комитет Республики Беларусь [Электронный pecypc]. URL: https://www.belstat.gov.by/viewer/?doclink=https://www.belstat.gov.by/upload-belstat/upload-belstatexcel/Oficial_statistika/Godovwe/Export_vne_SNG20g-1.xlsx\#1 (дата обращения: 16.08.2021); Импорт товаров в Республику Беларусь по отдельным странам вне CHГ // Национальный статистический комитет Республики Беларусь [Электронный ресурс]. URL: https://www.belstat.gov.by/viewer/?doclink=https://www.belstat.gov.by/upload-belstat/upload-belstat-excel/Oficial_statistika/Godovwe/Import_ vne_SNG20g-1.xlsx\#1 (accessed: 16.08.2021); Торгово-экономическое сотрудничество // Посольство Республики Беларусь в Боливарианской Республике Венесуэла [Электронный ресурс]. URL: https://venezuela.mfa.gov.by/ru/bilateral_relations/trade_economic/ (дата обращения: 16.08.2021). 


\section{Таблица 3}

Торговля товарами Республики Беларусь со странами Латинской Америки в 2016-2020 гг.

\section{(экспортно-импортные операции)}

млн. долл. США

\begin{tabular}{|c|c|c|c|c|c|c|c|c|c|c|}
\hline & \multicolumn{2}{|c|}{2016 г. } & \multicolumn{2}{|c|}{2017 г. } & \multicolumn{2}{|c|}{2018 г. } & \multicolumn{2}{|c|}{2019 г. } & \multicolumn{2}{|c|}{2020 Г. } \\
\hline & эксп. & имп. & эКсП. & имП. & ЭКсп. & имп. & эКсП. & имп. & эксп. & имп. \\
\hline Аргентина & 13,8 & 57,3 & 7,8 & 119,6 & 31,2 & 103,1 & 1,8 & 52,1 & 0,8 & 95,9 \\
\hline Бразилия & 441,0 & 82,8 & 439,9 & 72,6 & 585,5 & 125,7 & 584,2 & 304,9 & 540,4 & 177,9 \\
\hline Венесуэла & 2,0 & 0,0 & 10,0 & 0,2 & 2,5 & 0,2 & 0,3 & 0,1 & 1,1 & 0,2 \\
\hline Колумбия & 34,0 & 14,1 & 51,6 & 21,4 & 57,1 & 23,6 & 56,1 & 29,6 & 60,0 & 29,0 \\
\hline Куба & 18,8 & 48,3 & 21,8 & 38,2 & 15,3 & 1,6 & 10,5 & 1,6 & 5,4 & 1,1 \\
\hline Мексика & 3,1 & 23,3 & 3,9 & 28,2 & 20,1 & 36,7 & 12,9 & 30,9 & 14,3 & 26,5 \\
\hline Парагвай & 9,6 & 0,0 & 5,6 & 0,0 & 13,3 & 0,0 & 6,1 & 0,0 & 1,0 & 0,0 \\
\hline Перу & 5,9 & 4,3 & 9,8 & 5,1 & 14,2 & 6,7 & 9,4 & 7,1 & 0,7 & 6,1 \\
\hline Уругвай & 10,5 & 1,8 & 22,6 & 2,0 & 6,5 & 1,0 & 24,3 & 1,7 & 20,7 & 2,1 \\
\hline Чили & 0,8 & 10,6 & 2,9 & 14,6 & 2,9 & 22,1 & 3,3 & 17,9 & 0,8 & 17,8 \\
\hline Эквадор & 18,9 & 43,3 & 15,0 & 96,8 & 37,9 & 155,4 & 14,8 & 188,2 & 22,2 & 184,8 \\
\hline
\end{tabular}

Источник: Экспорт товаров из Республики Беларусь по отдельным странам вне СНГ // Национальный статистический комитет Республики Беларусь [Электронный pecypc]. URL: https://www.belstat.gov.by/viewer/?doclink=https://www.belstat.gov.by/upload-belstat/upload-belstatexcel/Oficial_statistika/Godovwe/Export_vne_SNG20g-1.xlsx\#1 (дата обращения: 16.08.2021); Импорт товаров в Республику Беларусь по отдельным странам вне CHГ // Национальный статистический комитет Республики Беларусь [Электронный ресурс]. URL: https://www.belstat.gov.by/viewer/?doclink=https://www.belstat.gov.by/upload-belstat/upload-belstat-excel/Oficial_statistika/Godovwe/Import_ vne_SNG20g-1.xlsx\#1/ (дата обращения: 16.08.2021); Торгово-экономическое сотрудничество // Посольство Республики Беларусь в Боливарианской Республике Венесуэла [Электронный ресурс]. URL: https://venezuela.mfa.gov.by/ru/bilateral_relations/trade_economic/ (дата обращения: 16.08.2021). 


\title{
Библиографические ссылки
}

1. Челядинский A. А. Белоруссия открывает окно в Латинскую Америку // Латинская Америка. 2008. №4. С. 56-64.

2. Андриевский К. П. Торговые отношения Республики Беларусь со странами Латинской Америки (1998-2008 гг.) // Журнал междунар. права и междунар. отношений. 2010. №2. С. 50-57.

3. Ананько К. Д. Влияние белорусско-кубинского торгово-экономического сотрудничества на экономическое развитие Республики Беларусь (1992-2017 гг.) // Государства Центральной и Восточной Европы в исторической перспективе : сб. научн. ст. по мат. II Междунар. научн. конф., Пинск 24-25 ноября 2017 г. : в 2 ч. / Полес. гос. ун-т ; под ред. Р. Б. Гагуа. Пинск: ПолесГУ, 2017. Вып. 2. Ч. 2. С. 89-92.

4. Ананько К. Д. Торгово-экономическое сотрудничество Республики Беларусь с Федеративной Республикой Бразилия в 1992-2018 гг. // Устойчивое развитие науки и образования. 2019. № 5. С. 74-80.

5. Андриевский К. П. Белорусско-кубинские связи (1992-2007 гг.) // Латинская Америка. 2009. № 12. С. 85-95.

6. Андриевский К. П. Отношения Республики Беларусь с Боливарианской Республикой Венесуэла (1997-2007 гг.) // Журнал междунар. права и междунар. отношений. 2009. № 1. С. 5156.

7. Кизима С. А. Белорусско-венесуэльская интеграция // Белорус. думка. 2010. № 2. С. 25-29.

8. Богдан C. Case study отношений Беларуси со странами Латинской Америки в 2002-2012 гг.

// Belarussian Institute for Strategic Study [Электронный pecypc]. 2013. URL: https://belinstitute.com/index.php/be/article/case-study-otnosheniy-belarusi-so-stranami-latinskoyameriki-v-2002-2012-gg (accessed: 15.08.2021).

9. Гусман Г. Ф., Челядинский $А$. А. Эквадор - Беларусь: курс на стратегическое партнерство (2007-2016 гг.). Минск: Право и экономика, 2017. 290 с.

10. Plevako I. Development of trade and economic relations of CIS countries with Latin America // Наукові записки Національного університету «Острозька академія». Сер. Міжнародні відносини. 2013. Вип. 3. С. 289-305.

11. Czachor R. Polityka zagraniczna Republiki Białoruś w latach 1991-2011. Studium politologiczne. Polkowice: Wyd. Dolnośląskiej Wyższej Szkoly Predsiębiorczości i Techniki w Polkowicach, 2011. 351 p.

12. Staśkiewicz L. Ameryka Lacińska w polityce zagranicznej Republiki Białoruś. Toruń: Wyd. Adam Marszałek, 2016. 189 p.

Дата поступления статьи: 01.09.2021.

Автор: Тихомиров Александр Валентинович - кандидат исторических наук, доцент, доцент кафедры международных отношений Белорусского государственного университета; e-mail: tihomirow@list.ru.

\section{LATIN AMERICA AS A FOREIGN POLICY PRIORITY OF THE REPUBLIC OF BELARUS (1992-2021)}

\author{
A.V. TSIKHAMIRAU \\ Belarusian State University, Minsk, Republic of Belarus
}

Abstract. The article assesses the place and role of Latin American countries
in the foreign policy of the Republic of Belarus in 1992-2021. The novelty of the re-
search lies in the consideration of the Latin American vector in the context of the for- 
eign policy strategy of the independent Belarusian state. The purpose of this article is to identify the features and evaluate the results of building relations between the Republic of Belarus and Latin American countries for three decades after it acquired the status of an independent state. The collected factual material of primary sources is analyzed using general scientific (analysis, synthesis, comparison, generalization, deduction) and special historical methods (historical-genetic, historical-comparative structural approach, systematic approach), as well as the method of descriptive analysis. The study reflects the transformation of Belarus' interaction with Latin American countries. It was noted that at the early stage of the existence of the independent Belarusian state, the development of relations with Latin American countries was not among the priorities of its foreign policy. In the second half of the 1990s, in the context of the implementation of the multi-vector approach in foreign policy, the activity of Belarusian diplomacy in the Latin American direction became more active and purposeful. In the 2000s - the first half of the 2010s, cooperation with Latin American states became one of the important foreign policy priorities of Belarus. The economic component prevailed in the development of relations with Latin America, although the coincidence of the political views of the Belarusian leadership and the leaders of individual Latin American states increased the effectiveness of interstate communication. In the second half of the 2010s, the effectiveness of the Belarusian diplomacy in the Latin American direction decreased for a number of reasons. However, the Belarusian leadership did not follow the path of a radical revision of the foundations of Latin American policy, hoping that the previously created developments will allow expanding cooperation in the future.

Keywords: The Republic of Belarus; Latin America; foreign policy; foreign policy priority; diplomacy; foreign trade.

For citation: Tsikhamirau A. (2021). Latinskaya Amerika kak prioritet vneshney politiki Respubliki Belarus' (1992-2021 gg.) [Latin America as a Foreign Policy priority of the Republic of Belarus (1992-2021)]. In: Actual problems of international relations and global development: collection of scientific papers. Minsk. Vol. 9. P. 117-141. https://doi.org/10.33581/2311-9470-2021-9-117-141

\section{References}

1. Chelyadinskij A. (2008). Belorussia otkryvajet okno v Latinskuju Ameriku [Belarus opens a window to Latin America]. In: Latin America, 2008, No. 4, p. 56-64. (in Russ.).

2. Andrijevskij K. (2010). Torgovyje otnoshenija Respubliki Belarus so stranami Latinskoj Ameriki (1998-2008 gg.) [Trade relations of the Republic of Belarus with Latin American countries (19982008)]. In: Journal of international Law \& international Relations, 2010, No. 2, p. 50-57. (In Russ.).

3. Anańko K. (2017). Vlijanije belorusko-kubinskogo torgovo-ekonomicheskogo sotrudinchestva na ekonimicheskoje razvitije Respubliki Belarus (1992-2017 gg.) [The impact of the BelarusianCuban trade and economic cooperation on the economic development of the Republic of Belarus (1992-2017)]. In: The states of Central and Eastern Europe in a historical perspective: collection of scientific articles on mat. II International Scientific Conference, Pinsk, 24-25.11.2017. Pinsk: Poles. GU, 2017, vol. 2, part 2, p. 89-92. (In Russ.). 
4. Anańko K. (2019). Torgovoje i ekonomicheskoje sotrudnichestvo Respubliki Belarus s Federativnoj Respublikoj Brazilija v 1992-2018 gg. [Trade and economic cooperation of the Republic of Belarus with the Federal Republic of Brazil in 1992-2018]. In: Sustainable development of science and education, 2019, No 5, p. 74-80. (In Russ.).

5. Andrijevskij K. (2009). Belorussko-kubinskije svjazi (1992-2007 gg.) [Belarusian-Cuban relations (1992-2007)]. In: Latin America, 2009, No 12, p. 85-95. (In Russ.)

6. Andrijevskij K. (2009). Otnoshenija Respubliki Belarus s Bolivarianskoj Respublikoj Venesuela (1997-2007 gg.) [Relations of the Republic of Belarus with the Bolivarian Republic of Venezuela (1997-2007)]. In: Journal of international Law \& international Relations, 2009, No. 1, p. 51-56. (In Russ.).

7. Kizima S. (2010). Belorussko-venesuelskaja integrazja [Belarusian-Venezuelan integration]. In: Belaruskaja dumka, 2010, No. 2, p. 25-29. (In Russ.).

8. Bogdan S. (2013). Case study otnoshenij Belarusi so stranami Latinskoj Ameriki [Case study of Belarus' relations with Latin American countries in 2002-2012]. Belarussian Institute for Strategic Study [Electronc Resource]. 2013. URL: https://belinstitute.com/index.php/be/article/case-study-ot nosheniy-belarusi-so-stranami-latinskoy-ameriki-v-2002-2012-gg (accessed: 15.08.2021) (In Russ.).

9. Gusman G., Chelyadinskij A. (2017). Ekvador - Belarus: kurs na strategicheskoje partnerstvo (2007-2016 gg.) [Ecuador - Belarus: a course for strategic partnership (2007-2016)]. Minsk: Pravo i economika, 2017, 290 p. (In Russ.).

10. Plevako I. (2013). Development of trade and economic relations of CIS countries with Latin America. In: Scientific notes of the National University "Ostroh Academy". International Relations, 2013, 3, p. 289-305.

11. Czachor R. (2011). Polityka zagraniczna Republiki Białoruś w latach 1991-2011. Studium politologiczne [The Foreign Policy of the Republic of Belarus in 1991-2011. Political science studies]. Polkowice: Wyd. Dolnośląskiej Wyższej Szkoly Predsiębiorczości i Techniki w Polkowicach, 2011, 351 p. (In Pol.).

12. Staśkiewicz L. (2016). Ameryka Lacińska w polityce zagranicznej Republiki Białoruś [Latin America in the foreign policy of Belarus]. Toruń: Adam Marszałek, 2016, 189 p. (In Pol.).

Received: 01.09.2021.

About author: Tsikhamirau Aliaksandr - Candidate of Historical Sciences, Associate Professor, Department of International Relations, Belarusian State University; mail: tihomirow@list.ru. 